\title{
Simulation of human bone implant duralium material with variation loading using Ansys software
}

\author{
Didin Mujahidin ${ }^{1}$, Poppy Puspitasari ${ }^{1,2 *}$ and Djoko Kustono ${ }^{1}$ \\ ${ }^{1}$ Department of Mechanical Engineering, Faculty of Engineering, State University of Malang, 65145 \\ Malang, Indonesia \\ ${ }^{2}$ Center of Advanced Materials, State University of Malang, 65145 Malang, Indonesia
}

\begin{abstract}
Bone implants are a tool used as a support of body parts, and bone support in cases of fractures. Scaffold, plate, bone screw, and some other tools can be used in combination to support and fill the connection between broken bones before the tissue grows. The most commonly used implant materials are Titanium, Stainless steel and ceramics, which are very common in the use of medical devices. Biocompatible materials are taken into consideration when planning a medical device. This research intended to know the durability of duralumin material as the latest implant material, as the development and breakthrough in health world. The research methodology used in this study was the optimization in Ansys software 18.1. The implants were designed, the material strength was determined and then given imposition with 6 variations $(450 \mathrm{~N}, 550 \mathrm{~N}, 650$ $\mathrm{N}, 750 \mathrm{~N}, 850 \mathrm{~N}$ and $950 \mathrm{~N}$ ). The optimization was a method that identified mat erial strength including Equivalent Stress, Shear Stress and Total Deformation of duralumin material as implant materials with loading variations. Based on the results of the research, the duralumin material had a equivalent stress of $475,700 \mathrm{~Pa}$ which was higher than $950000 \mathrm{~Pa}$ for $\mathrm{ZnO}-\mathrm{Al} 2 \mathrm{O} 3$ implants, while the duralumin shear stress of $1084500 \mathrm{~Pa}$ was higher than $313720 \mathrm{~Pa}$ for $\mathrm{ZnO}-\mathrm{Al} 2 \mathrm{O} 3$ implants. When compared with titanium implants, the highest equivalent stress of $150000 \mathrm{~Pa}$ duralumin material had a higher compression stress than titanium. The highest shear stress of titanium 4358.1 $\mathrm{Pa}$ means an implant with a higher shear duralumin material of titanium. Whereas if it was compared to stainless steel with voltage press $564000000 \mathrm{~Pa}$, then the duralumin's pressure was getting lower. Material hardness affects resistance to wear and tear. Duralumin material hardness was lower than Titanium and $\mathrm{ZnO}-\mathrm{Al} 2 \mathrm{O} 3$, so total Duralumin deformation (elasticity) was higher than Titanium and $\mathrm{ZnO}-\mathrm{Al} 2 \mathrm{O} 3$.
\end{abstract}




\section{Introduction}

Bone implants are a tool used as a support of body parts, and bone support in cases of fractures. Scaffold, plate, bone screw, and some other tools can be used in combination to support and fill the connection between broken bones before the tissue grows. Because of that scaffold, in the bone area will experience direct contact with bone cells, including osteoblasts, osteocytes, and osteoclasts. And the scaffold must have characteristics as well as the loading criteria and the mechanical motion of the bone. These factors will affect the rate of bone growth and the decay of the scaffold [7].

Indonesia has a significant number of cases of bone surgery, ranging from 300 to 400 cases of bone surgery monthly. The need for endospores of the knee joint is statistically more numerous, than the endoprosthetic needs of other body parts (Sopyan Iis: 2007). Damage to joints (osteoarthritis) can be treated with total knee replacement by replacing the knee joint using prostheses [2].

Knee joints are the largest joints that lie between the joints of the ankles and hip joints. The knee joint is formed by the femoral, tibia, and patella bone [8]. Knee joints can withstand loads of 3-4 times the weight of the human body [4]. However, the knee joint is a susceptible organ that is damaged by the activities and workloads of everyday people. The presence of disease, the occurrence of accidents, and increasing age are some of the factors that can cause damage to the knee joint. If the damage to the knee joint is so severe, then the steps taken are total knee replacement (TKR). Until recently, standard implant materials for knee joints were made of metal and polymer pairs.

Implant of metals into the body can cause swelling and pain around the implanted tissues. The metal solution is coated with a biomaterial that has a good biocompatibility with body cells. The material used for implant coating material is Hydroxyapatite (HAp). HAp is the main inorganic composite of bone. Including bioactive ceramic material with high bioffinity which is biocompatible and has similar composition and biological with bone. The bioactive nature of hydroxyapatite is helpful for bone regeneration in the formation and development of cells around the tissues. Hydroxyapatite in addition to improving the biocompatibility of implantable materials, as well as porous materials that serve as interface materials, between implant materials and human tissue. The main part of the total knee joint replacement is a knee cap prosthetic which in this study is made from a cobalt-based alloy material modified with the addition of Nitrogen elements to suppress the growth of $\varepsilon$ and $\sigma$ phases, which are brittle, lowering CoCrMo's alloy fatigue strength [1].

In addition to being used in the automotive industry, aluminum is also being used in the medical equipment industry. Besides, it is not pure aluminum which is used in medical devices but rather fusion of aluminum and other metals. The fusion commonly used in medical devices is duralumin. According to [3], the components of the duralumin fusion

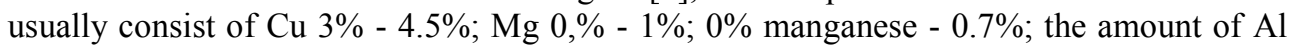
adjusts the composition; Ir $0.4 \%-1 \%$; Si $0.3 \%-0.6 \%$.

The focus of this study was to identify the distribution of material voltage due to static loading which is varied according to the weight of the use of the implant. This research is aimed to know the strength of duralumin to the natural loading in order to the selection of bone implant material will not occur the selection of materials that are fatal for bone implant users.

\section{Methodology}

The research used in this research was descriptive experimental quantitative research. It is said to be quantitative descriptive because the researcher aims to describe the strength of the duralumin material as an implant. The strength of the material to be targeted has been 
defined as the dependent variable that is the mechanical properties of duralumin. The experimental quantitative is based on the results of the research that the researchers describe based on the manipulation of random variables (variations of loading including weight of implant users) starting from $45 \mathrm{~kg}, 55 \mathrm{~kg}, 65 \mathrm{~kg}, 75 \mathrm{~kg}, 85 \mathrm{~kg}$, and $95 \mathrm{~kg}$ and control variables (static loading on implants) that have been planned.

In this study, the process is done by simulation on the implant using Ansys 18.1 software before simulating many things that have to be prepared, such as the design of implants with predetermined size, the characteristics of the implant material that must be known. The characteristics that must be known include modulus's young, poisson's ratio and density. The data can be obtained from various journals and books that already exist.

Table 1. Material Properties of Duralumin

\begin{tabular}{lccccc}
\hline \multirow{2}{*}{$\begin{array}{c}\text { Material } \\
\text { Young's Modulus } \\
(\mathrm{MPa})\end{array}$} & $\begin{array}{c}\text { Shear } \\
\text { Modulus }\end{array}$ & $\begin{array}{c}\text { Poisson's } \\
(\mathrm{MPa})\end{array}$ & $\begin{array}{c}\text { Melting point } \\
\left({ }^{\circ} \mathrm{C}\right)\end{array}$ & $\begin{array}{c}\text { Density } \\
\left(\mathrm{Kg} / \mathrm{m}^{3}\right)\end{array}$ \\
\hline Duralumin & $0.73 \times 10^{5}$ & 283 & 0.33 & $502-638{ }^{\circ} \mathrm{C}$ & 2800
\end{tabular}

Source: CRP MECCANICA S.r.l. Sede Legale e Amministrativa/Headquarters and Administration Office Via Cesare Della Chiesa 21 - 41126 Modena

After design and material data is determined, then the simulation process can be done. We will describe briefly the simulation process, with the first step is to enter the data material, insert the design into Ansys, then the determination of the material on the implant, after that the process of loading and final stage is to determine the results that are shown from the simulation process. The results of the simulation process can be a shear stress, equivalent stress, elasticity and even other results. For the output can be written data, pictures and video.

\section{Results and Discussion}

The data generated in this research are numerical, analytical and exposure drawing which include mechanical properties. The mechanical properties consist of equivalent stress, shear stress and elasticity using Ansys. The effect of Voltage Variation Testing is done in the laboratory Design and Simulation in Universitas Negeri Malang. Mechanical properties testing on implants aims to determine the quality of a material in the implant. The mechanical properties consist of equivalent stress, shear strength and elasticity. The following is an illustration and table describing the durational implant test results with 6 variations of loading $(450 \mathrm{~N}, 550 \mathrm{~N}, 650 \mathrm{~N}, 750 \mathrm{~N}, 850 \mathrm{~N}$ and $950 \mathrm{~N})$. 


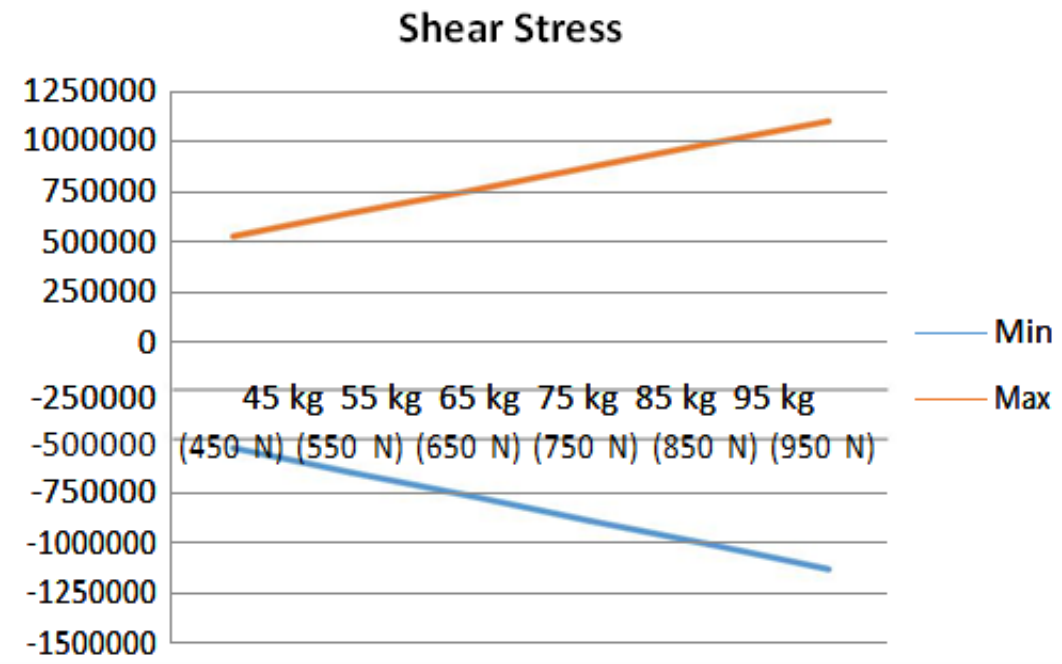

Fig. 1. Diagram of Analytical Line of Shear Stress

From the various simulation results for shear stress, the minimal results were obtained in implant users with a $45 \mathrm{~kg}$ weight of $-541530 \mathrm{~Pa}$. As for the greatest thing found in users of implants with a weight of $95 \mathrm{~kg}$ of $1084500 \mathrm{~Pa}$.

\section{Elasticity}

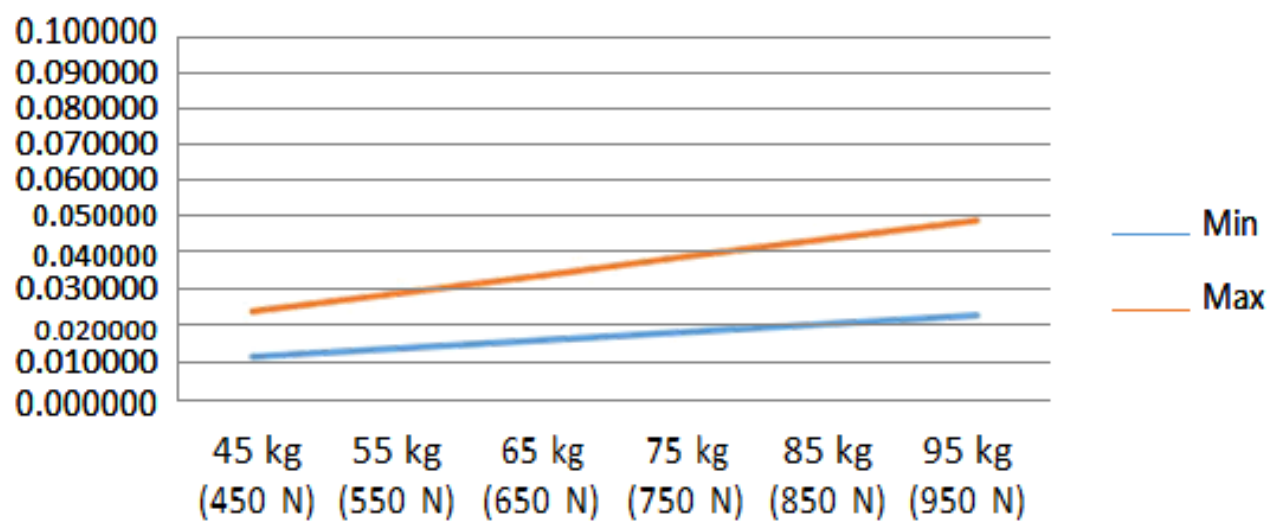

Fig. 2. Diagram of Analytical Line of Elasticity (Total Deformation)

For Total Deformation, the minimal results for total deformation were found in implant users with a weight of $45 \mathrm{~kg}$ of $0.010595 \mathrm{~mm}$. As for the greatest thing found in users of implants with a weight of $95 \mathrm{~kg}$ of $0.04903 \mathrm{~mm}$. 


\section{Equivalent Stress}

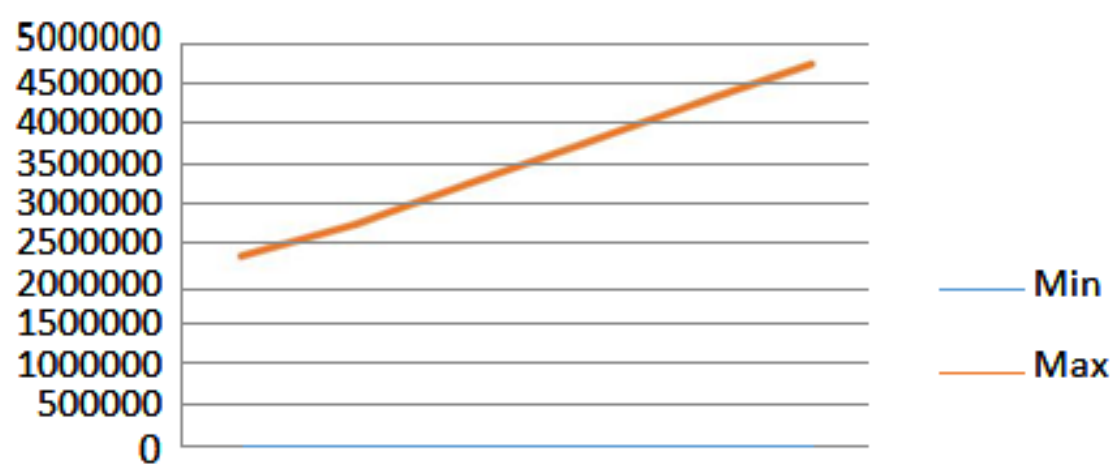

45 kg 55 kg 65 kg 75 kg 85 kg 95 kg

(450)(550) (650 (750 (850) (950

$\begin{array}{lllll}\mathrm{N}) & \mathrm{N}) \quad \mathrm{N}) \quad \mathrm{N}) \quad \mathrm{N}) \quad \mathrm{N})\end{array}$

Fig. 3. Diagram of Analytical Line of Equivalent Stress

Meanwhile, the simulation results for Equivalent Stress, the minimal results were obtained in implant users with a $45 \mathrm{~kg}$ weight of $105 \mathrm{~Pa}$. As for the greatest thing found in users of implants with a weight of $95 \mathrm{~kg}$ of 475,700 Pa.

From the various graphs, the simulation results show an increase ranging from equivalent stress, shear stress and elasticity. For more details, take a look at simulated images on Ansys 18.1. For the image we display with the highest loading (950 N).

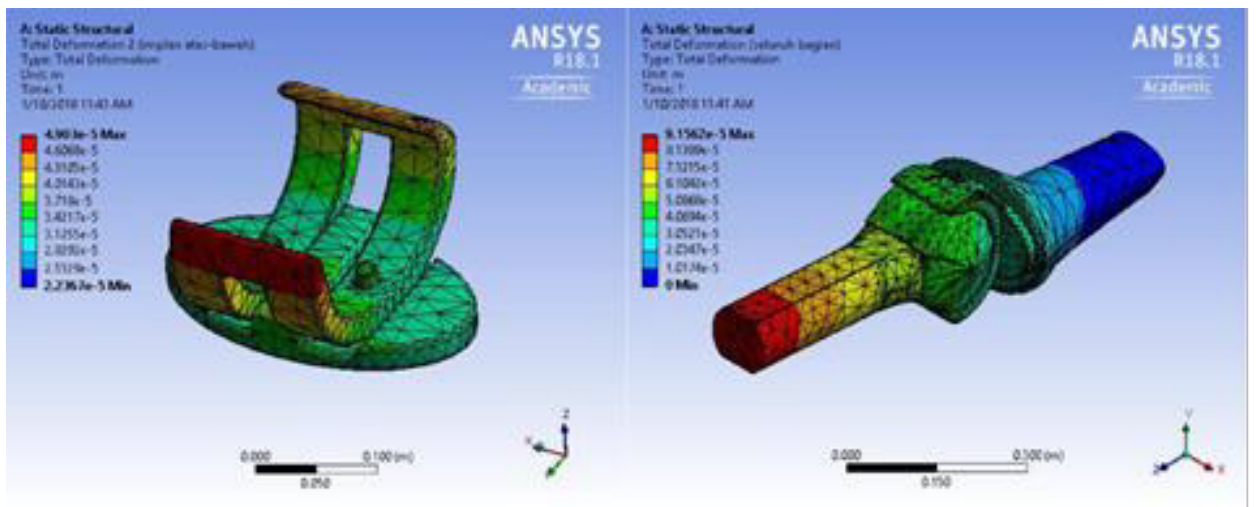

Fig. 4. Analysis of Mechanical Properties (Total Deformation) with loading $950 \mathrm{~N}$ to Implant. 


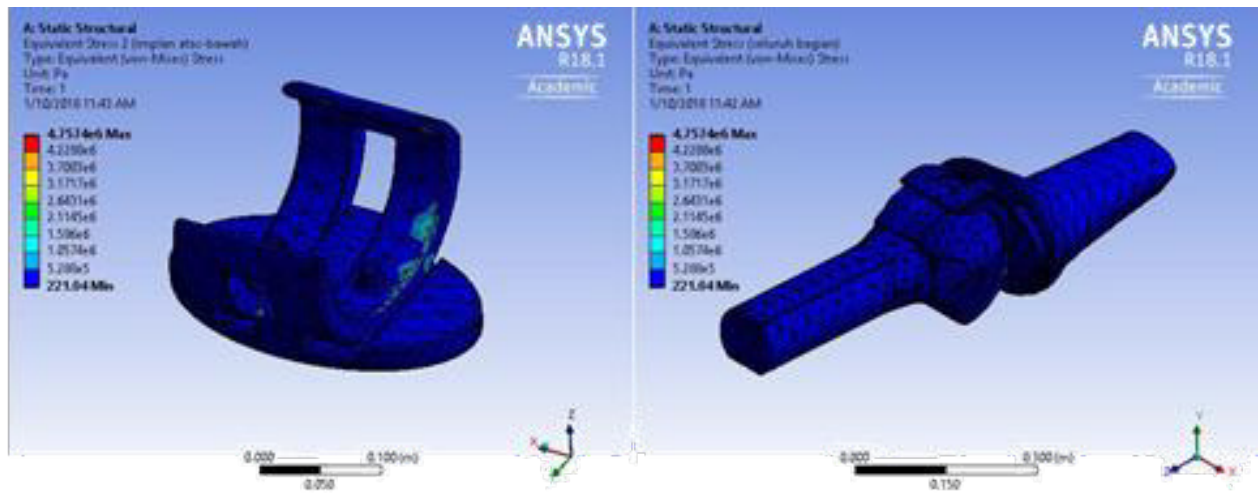

Fig. 5. Analysis of Mechanical Properties (Equivalent Stress) with loading $950 \mathrm{~N}$ to Implant.

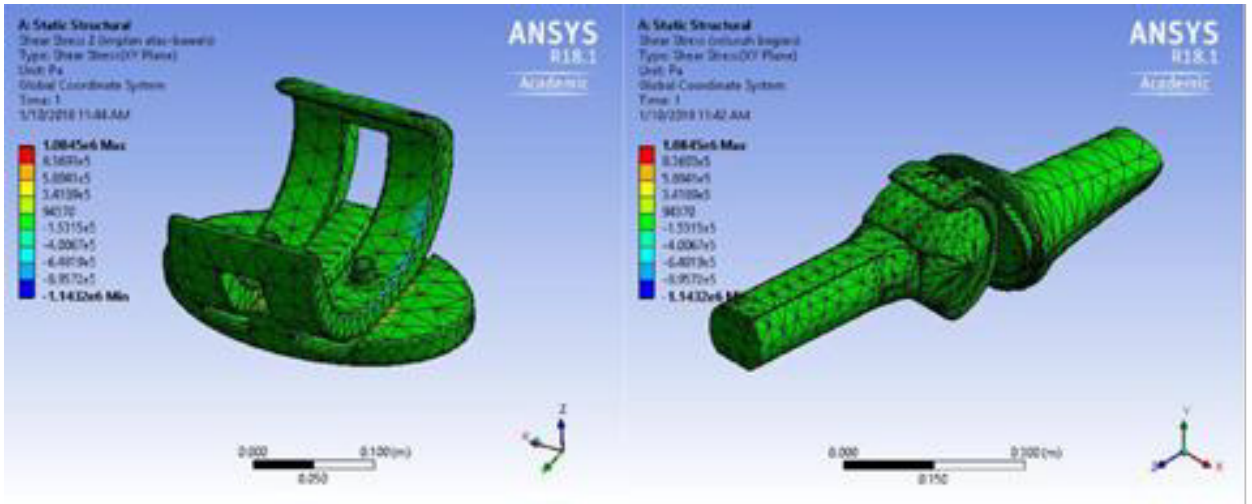

Fig. 6. Analysis of Mechanical Properties (Shear Stress) with loading $950 \mathrm{~N}$ to Implant.

Table 2. Analysis Result of Mechanical Properties Testing of Implant on All Loading

\begin{tabular}{|c|c|c|c|c|c|c|}
\hline \multirow[b]{2}{*}{ Force } & \multicolumn{2}{|c|}{ Total Deformation (mm) } & \multicolumn{2}{|c|}{ Equivalent Stress $(\mathrm{Pa})$} & \multicolumn{2}{|c|}{ Shear Stress $(\mathrm{Pa})$} \\
\hline & Min & Max & Min & Max & Min & Max \\
\hline $\begin{array}{c}45 \mathrm{~kg} \\
(450 \mathrm{~N})\end{array}$ & 0.010595 & 0.023225 & 105 & 2353500 & -541530 & 513690 \\
\hline $\begin{array}{c}55 \mathrm{~kg} \\
(550 \mathrm{~N})\end{array}$ & 0.012949 & 0.028386 & 128 & 2754300 & -661870 & 627840 \\
\hline $\begin{array}{r}65 \mathrm{~kg} \\
(650 \mathrm{~N})\end{array}$ & 0.015303 & 0.033547 & 152 & 3255100 & -782210 & 742000 \\
\hline $\begin{array}{r}75 \mathrm{~kg} \\
(750 \mathrm{~N})\end{array}$ & 0.017658 & 0.038708 & 175 & 3755900 & -902560 & 856150 \\
\hline $85 \mathrm{~kg}$ & 0.020012 & 0.043869 & 198 & 4256600 & -1022900 & 970300 \\
\hline
\end{tabular}


$(850 \mathrm{~N})$

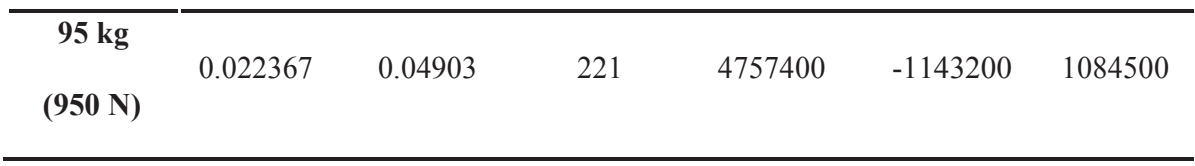

From the results of research about the distribution of stress on the implant with duralumin material that has been optimized with Ansys software got a lot of data about the material endurance. The data obtained include equivalent stress, shear stress and material elasticity with 6 variations of loading. At the lowest tensile stress, it was found that the lowest tension was $105 \mathrm{~Pa}$ and the highest was $2353500 \mathrm{~Pa}$. While loading with the highest variation, it was found that the lowest tension was $221 \mathrm{~Pa}$ and the highest was $4757400 \mathrm{~Pa}$. For implant equivalent stress with non-durable materials that have been presented in the previous study, $\mathrm{ZnO}-\mathrm{Al} 2 \mathrm{O} 3$ has the highest value of $950000 \mathrm{~Pa}[6]$, which means that the duralumin material has a higher compressive stress than $\mathrm{ZnO}-\mathrm{Al} 2 \mathrm{O} 3$.

The shear stress with the lowest loading variation was found that the lowest shear stress was $-541530 \mathrm{~Pa}$ and the highest was $513690 \mathrm{~Pa}$. While loading with the highest variation was found that the lowest shear stress was $-1143200 \mathrm{~Pa}$ while the highest was $1084500 \mathrm{~Pa}$. For implant shear stresses with non-durable materials that were presented in the previous study, $\mathrm{ZnO}-\mathrm{Al} 2 \mathrm{O} 3$ has the highest value of $313720 \mathrm{~Pa}$ [6], the data means that duralumin material has a higher shear stress than $\mathrm{ZnO}-\mathrm{Al} 2 \mathrm{O} 3$. The big difference in Duralumin and $\mathrm{ZnOAl} 2 \mathrm{O} 3$ pressure is because the difference of young modulus and Poisson ratio on each material. This difference affects the durability of the material that accepts the load and distributes the load. This is indicated by the difference in stress that occurred in both the implant material and the color difference at the stress distribution level that occurs in the implant.

When compared to titanium implants that have the highest equivalent stress of 150000 $\mathrm{Pa}$, the duralumin material has a higher equivalent stress than titanium. For the highest shear stresses of titanium is $4358.1 \mathrm{~Pa}$ which means implants with higher shear duralumin material of titanium.

At equivalent stresses of the duralumin implants with various user weight and implants used in normal walking activity, it was found that the lowest tension was $105 \mathrm{~Pa}$ and the highest was 475,700 $\mathrm{Pa}$. For implant press stress in previous research with stainless steel having the highest value of $564000000 \mathrm{~Pa}$ [6], the data means that duralumin material has lower equivalent stress than stainless steel.

The hardness properties can affect the wear resistance of a material. This may affect the wear factor, where higher hardness materials can result in lower UHMWPE pin factor [5]. A rigid material has a high Young Modulus and changes its shape slightly below the elastic load. For Duralumin material itself, the greatest modulus of young is compared to Titanium and $\mathrm{ZnOA12O3}$, which means the wear factor of implant with duralumin is higher when compared with the two materials.

\section{Conclusions}

In the test results the stress distribution consists of equivalent stress, shear stress and elasticity with various loading variations. For the shear stresses that occur in the duralumin implant obtained data $-1143200 \mathrm{~Pa}$ for the lowest and highest value is $1084500 \mathrm{~Pa}$. When compared with previous research the duralumin material has a higher shear stress than $\mathrm{ZnO}-\mathrm{Al} 2 \mathrm{O} 3$ which has the highest shear stress of $313720 \mathrm{~Pa}$ and titanium which has a shear 
stress of $4358.1 \mathrm{~Pa}$. For the equivalent stress that occurs in the duralumin implants, the data of $221 \mathrm{~Pa}$ for the lowest and highest is $475,700 \mathrm{~Pa}$. When compared with previous research the duralumin material has a higher equivalent stress than $\mathrm{ZnO}-\mathrm{Al} 2 \mathrm{O} 3$ which has the highest compressive stress of $950000 \mathrm{~Pa}$ and titanium which has the highest equivalent stress of $150000 \mathrm{~Pa}$. However, when compared with stainless steel implants with the highest value of $564000000 \mathrm{~Pa}$, the duralumin implant has a lower equivalent pressure. Material hardness affects resistance to wear and tear. Duralumin material hardness is lower than Titanium and $\mathrm{ZnO}-\mathrm{Al} 2 \mathrm{O} 3$. Thus the total deformation (elasticity) of Duralumin is higher than Titanium and $\mathrm{ZnO}-\mathrm{A} 12 \mathrm{O} 3$. The greater the weight of the implant user will increasingly affect the distribution of stress that occurs in the implant.

\section{References}

1. Giat, Sulistioso et al, Making Knee Joint Prosthetic Prototypes, Tangerang Selatan: PTBIN - BATAN. PUPIPTEK (2000)

2. Hong Li, Chang-RenZhou, Min-Yin Zhu, Jin-Huan Tian, Jian-Hua Rong, Journal of Biomaterials and Nanobiotechnology, 42-49. (2010)

3. Merica, P. D. and Waltenberg, R. G, and Scott H, Heat Treatment of Duralium, Scientific Papers of the Bureau of Standart (1919)

4. Morrison, J.B, J. Biomech., 3 (1970)

5. Prayoga, Benidiktus Tulung., Arfan F, Rini Dharmastiti, Suyitno, Jurnal Material Teknologi Proses (2015)

6. Puspitasari, Andoko, ARPN Journal of Engineering and Applied Sciences, (2016)

7. Saito, The Journal of Heart and Lung Transplantation. (2011)

8. Tortora, G.J. Derrickson, B, Principles of Anatomy and Physiology. 14 ed, John Wiley \& Sons, New Jersey, Chap 9 (2000) 